\title{
AUTOIMMUNE HUMAN SPERM ANTIBODIES AND AGE IN MALES
}

\author{
BO FJÄLLBRANT \\ Department of Obstetrics and Gynaecology, University of Göteborg, Sweden*
}

(Received 16th September 1974)

\begin{abstract}
Summary. The incidence of autoimmunization to spermatozoa, investigated by means of the Kibrick technique, increased with age in 913 males unselected with regard to fertility. By contrast, the incidence of sperm agglutinin-positive sera decreased with age in 1600 male partners in sterile couples. The increasing incidence of autoimmunization to spermatozoa offers one explanation of the lowering of fertility with increasing age, but sperm antibodies seem to be more important as a cause of sterility at younger ages. The presence of spermatozoa may not be necessary for immunization since sperm agglutinins were found in a 9-year-old boy.
\end{abstract}

Sperm antibodies account for 3 to $4 \%$ of male sterility, but the cause of the formation of these autoimmune antibodies is still obscure. In order to examine this problem and elucidate the necessity of spermatozoa for the immunization process, we investigated the incidence of sperm antibodies in the blood of males of different ages unselected with regard to fertility. In order to establish the rôle of sperm antibodies as a sterility factor at different ages, the results for an 'unselected population' were compared with the distribution of sperm immunization in a 'selected population'.

The group of males unselected with regard to fertility partly comprised 137 boys 9 to 10 years old. They belonged to school classes in which the majority of the boys volunteered for the investigation. The group also comprised 775 blood donors distributed with regard to age as shown in Table 1.

The 'sterile group' comprised 1600 male partners of couples who attended our clinic because of sterility. It had not been established that the men were the cause of the sterile union. The distribution of the men in this group with regard to age is given in Table 2.

Blood serum samples were investigated for the presence and titre of sperm agglutinins by the macroscopic direct sperm agglutination technique of Kibrick, slightly modified as described in an earlier paper (Fjällbrant, 1968). The sera were screened at a dilution of 1:4. For determination of titre, the positive sera were serially diluted twofold. One donor furnished all the semen samples used for the investigation of the group unselected with regard to fertility and for more than 500 men in the sterile group. The other men in this group were investigated using ejaculates from several donors. All semen specimens were of

* Postal address: KK, Östra sjukhuset, S-416 85 Göteborg, Sweden. 
good quality and without spontaneous agglutination. The data were subjected to statistical analysis, using the $\chi^{2}$ test.

The incidence of sperm agglutinin positive sera increased significantly $(P<0.01)$ with age in the 'unselected' males (Table 1). Among the 137 prepubescent boys, one 9-year-old had sperm agglutinins in his serum. The titre

Table 1. Age distribution and incidence of sperm agglutinin-positive sera and high titres $(\geq 1: 64)$ in males unselected with regard to fertility

\begin{tabular}{|c|c|c|c|c|c|}
\hline \multirow[b]{2}{*}{ Age (years) } & \multirow[b]{2}{*}{$\begin{array}{l}\text { No. of } \\
\text { subjects }\end{array}$} & \multicolumn{2}{|c|}{ Positive } & \multicolumn{2}{|c|}{ High titres } \\
\hline & & $\begin{array}{l}\text { No. of } \\
\text { subjects }\end{array}$ & $\%$ & $\begin{array}{l}\text { No. of } \\
\text { subjects }\end{array}$ & $\%$ \\
\hline $\begin{array}{l}9 \text { to } 10 \\
18 \text { to } 19 \\
20 \text { to } 29 \\
30 \text { to } 39 \\
40 \text { to } 49 \\
50 \text { to } 59\end{array}$ & $\begin{array}{r}137 \\
123 \\
285 \\
176 \\
90 \\
102\end{array}$ & $\begin{array}{r}1 \\
4 \\
14 \\
6 \\
7 \\
10\end{array}$ & $\begin{array}{l}0 \cdot 7 \\
3 \cdot 3 \\
4 \cdot 9 \\
3 \cdot 4 \\
7 \cdot 8 \\
9 \cdot 8\end{array}$ & $\begin{array}{l}0 \\
1 \\
2 \\
3 \\
1 \\
3\end{array}$ & $\begin{array}{l}0 \\
0.8 \\
0.7 \\
1.7 \\
1.1 \\
2.9\end{array}$ \\
\hline Total & 913 & 42 & 4.6 & 10 & $1 \cdot 1$ \\
\hline
\end{tabular}

Table 2. Age distribution and incidence of sperm agglutinin positive sera and high titres $(\geq 1: 64)$ in male partners of sterile couples

\begin{tabular}{ccccccc}
\hline & & \multicolumn{2}{c}{ Positive } & & \multicolumn{2}{c}{ High titres } \\
\cline { 7 - 7 } Age (years) & $\begin{array}{c}\text { No. of } \\
\text { men }\end{array}$ & $\begin{array}{c}\text { No. of } \\
\text { men }\end{array}$ & $\%$ & & $\begin{array}{c}\text { No. of } \\
\text { men }\end{array}$ & $\%$ \\
\hline 20 to 29 & 695 & 78 & $11 \cdot 2$ & 30 & $4 \cdot 3$ \\
30 to 39 & 778 & 74 & $9 \cdot 5$ & 26 & $3 \cdot 3$ \\
40 to 49 & 113 & 6 & $5 \cdot 3$ & 2 & $1 \cdot 8$ \\
50 to 57 & 14 & 0 & 0 & 0 & 0 \\
Total & 1600 & 158 & $9 \cdot 9$ & & 58 & $3 \cdot 6$ \\
\hline
\end{tabular}

was low, $1: 16$. To confirm this finding, blood samples were taken twice at an interval of 3 weeks. The result was the same with both specimens. When examined by a paediatrician-endocrinologist, he was found to be normally developed with regard to his age.

For the men in the sterile group, a tendency to a decrease in the incidence of autoimmunization with age was observed (Table 2). For the ' 20 to 29' and ' 30 to 39' age groups, the incidence of autoimmunization to spermatozoa was significantly higher in the sterile than in the unselected group $(P<0.01)$. For the ' 40 to 49 ' age group, the incidence was similar in both groups.

There was a significantly greater incidence of high titres in the males in the 'selected' group than for those in the 'unselected' group. Such a difference has been shown earlier (Rümke \& Hellinga, 1959; Fjällbrant, 1968). The incidence of high titres also decreased with age in the sterile group. 
The reverse distribution of autoimmunization to spermatozoa with regard to age for the subjects in the two groups is clearly shown in Text-fig. 1.

This investigation indicates that the incidence of autoimmunization to spermatozoa normally increases with age. Before puberty, sperm antibodies are found only occasionally, but they become more frequent in older teenagers. In their fifties, $10 \%$ of males have autoantibodies against spermatozoa. Investigating men of 67 or more years of age with the same technique, Hamerlynck (1970) found sperm agglutinins in $16 \%$, a figure that fits well with the results of the present investigation. In the same men, Rümke (1971) found a correlation between the presence of sperm antibodies in the blood during life and signs of extravasation of spermatozoa in the epididymis after death. He suggested that

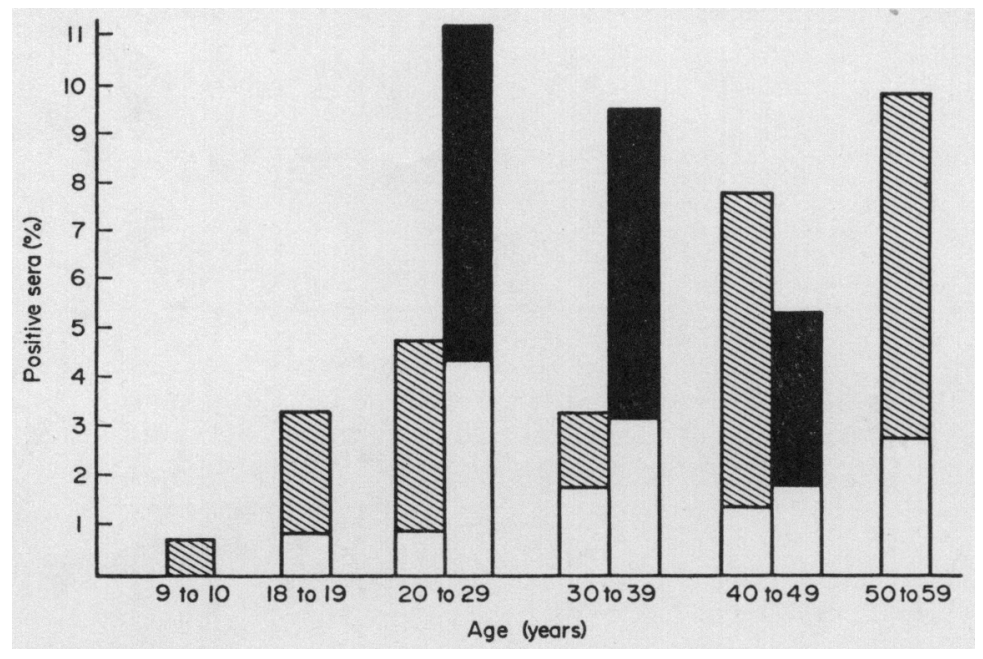

Texr-FIG. 1. Incidence of sperm agglutinin-positive sera and high titres $(\geqslant 1: 64$, open columns) with age in a group of males unselected with regard to fertility (hatched columns) and a group of male partners of sterile couples (solid columns).

the formation of sperm antibodies was caused by absorption of sperm material. A correlation of sperm antibodies and prostatitis has also been suggested (Fjällbrant \& Obrant, 1968). This would agree with the observation that there is an increase in the incidence of prostatitis with age. The finding of sperm agglutinins in the blood of a 9-year-old boy, i.e. at an age when spermatozoa should not be present, indicates the possibility of a cross-reaction, the immunization having occurred against bacterial or other antigens.

The correlation between sperm antibodies and age suggests one factor which can bring about the reduction of fertility with age. The decreasing incidence of autoimmunization to spermatozoa in the men in the sterile group is subject to several possible explanations; one of these involves certain selection mechanisms, for example a greater increase of other sterility factors with increasing age.

The investigation was supported by a grant from the University of Göteborg (the Hjalmar Svensson foundation). Indispensable assistance was given by the 
school health authorities of Göteborg (Dr Ragnar Olegård and Miss Maja Garton) and the Blood Bank, Sahlgren hospital (Dr Lena Sandberg).

\section{REFERENCES}

FJällbrant, B. (1968) Sperm agglutinins in sterile and fertile men. Acta obstet. gynec. scand. 47, 89-101. Fjällbrant, B. \& Obrant, O. (1968) Clinical and seminal findings in men with sperm antibodies. Acto obstet. gynec. scand. 47, 451-468.

HAMERLynck, J. V. T. H. (1970) Cytotoxic and other auto-antibodies against spermatozoa in relation to infertility in the human male. Thesis, Amsterdam.

RümkE, P. (1971) Autoantikörperbildung gegen Spermatozoen infolge Extravasation von Spermatozoen ins Interstitium der Epididymis älterer Männer. Schweiz. med. Wschr. 101, 1439-1441.

Rümke, P. \& Hellinga, G. (1959) Autoantibodies against spermatozoa in sterile men. Am. F.clin. Path. 32, 357-363. 